\title{
Qual Deveria Ser o Nome da Back Schoo/ Brasileira?
}

Aos Editores: A edição no 4 (jul/ago), Volume 45, da Revista Brasileira de Reumatologia (RBR) publicou um artigo de Sandra Cristina de Andrade e colaboradores ${ }^{(1)}$, trazendo uma revisão histórica sobre a Back School, traduzida para "Escola de Coluna".

Os autores apontam que, realmente, em vários países, a primitiva designação dada pelos suecos de Back School foi traduzida de maneiras diferentes.

Iniciei, como é referido nesse artigo, em 1972, na Ortopedia do Hospital do Servidor Público Estadual. Esse tipo de atividade é caracterizada, como diz o próprio nome, por uma espécie de escola, aonde os pacientes recebem aulas com slides e vídeos. São reunidas de 20 a 40 pessoas com dores na coluna vertebral para que aprendam posturas adequadas nas atividades do dia-a-dia visando a prevenção do aparecimento de novas dores.

Essa é a grande diferença da primitiva Back School, que dava muita ênfase à explicação anatômica das dores, a qual empenhava-se exageradamente em resolvê-las aplicando exercícios físicos da famosa Escola Sueca de Educação Física. Quando começamos essa atividade no Hospital do Servidor, também passamos a tratar dos problemas sóciopsicossomáticos que estavam associados a dores crônicas da coluna (em 1972, não existia a fibromialgia, mas existia a denominação fibrosite, que tinha as mesmas características nestes pacientes crônicos). Assim, denominamos de Escola de Postura esse tipo de atividade por duas razões: $1^{\circ}$ ) A Back School sueca que fui visitar em Gotemburgo, dava absoluta ênfase aos exercícios físicos. Na Escola de Postura, dávamos maior ênfase aos exercícios de relaxamento, baseados no treinamento autógeno de Schultz; $2^{\circ}$ ) Na Escola de Postura incluía-se a preocupação dos fatores sóciopsicossomáticos e sexuais na gênese das dores crônicas, e para isso fazíamos referência à terapia cognitiva comportamental (TCC).

Essa terapia não-Freudiana procura analisar a relação entre as pessoas da família, do ambiente do trabalho e da qualidade de vida que o paciente adotou em se tornar uma

\section{REFERÊNCIAS}

1. Andrade SC, Araújo GR, Vilar MJP: Escola de Coluna: Revisão Histórica e sua Aplicação na Lombalgia Crônica. Rev Bras Reumatol, 45: 224-228. 2005. pessoa com dor crônica, para justificar a sua depressão, ansiedade, medos, falta de sono, fadiga, vontade de aposentadoria precoce, infelicidade no casamento, etc.

Isto significava uma mudança de postura não só ergonômica, no modo de sentar, dormir, andar, mas uma mudança de postura em relação à própria vida. Dessas aulas, surgiu o livro "Viva bem com a coluna que você tem", que em Outubro de 2005 teve sua $31^{\text {a }}$ edição lançada, com 167 mil livros vendidos.

Participei, em 1981, no Congresso Mundial de Ortopedia, realizado no Rio de Janeiro, de uma mesa redonda com os professores Alf Nacheson, Hall, e mais três outros. $\mathrm{Na}$ ocasião, apresentei este modelo, obtendo uma referência elogiosa do Prof. Nacheson.

Parabenizo a Sandra Cristina de Andrade e sua equipe pelo interesse e pelo belo artigo de revisão sobre o tema. Gostaria também de finalizar comentando que a denominação de Escola de Coluna, numa pesquisa que fiz há muitos anos ,não era compreendida pelos pacientes. Portanto, minha sugestão aos autores do artigo em questão, seria que checassem com os pacientes se conseguem distinguir o que significa Escola de Coluna e Escola de Postura. Qual seria a designação mais compreensível, e talvez pudesse sugerir à Sociedade Brasileira de Reumatologia (SBR) qual o termo mais adequado para designação dessa atividade no Brasil. Também gostaria de citar que a 3 a edição do "Enfermidades da Coluna Vertebral" de $2003^{(1)}$ traz uma revisão sobre este tema, baseado em evidências não só da Cochrane Library, mas também da SBU (Swedish Council on Technology Assessement in Health Care) - em sueco, é a revisão baseada em evidências da vasta literatura sobre coluna e Back School, aplicada nos países escandinavos - praticamente inacessível à maioria dos pesquisadores que usam a literatura do Medline. SBU foi amplamente referido no último livro do Prof. Nacheson ${ }^{(3)}$, o qual traz uma série de trabalhos que poderiam ser utilizados pelos autores do artigo citado para confrontar e conferir as últimas evoluções da Escola de Postura no mundo.

José KNOPLICH

Ex-diretor do Grupo de Algias da Coluna Vertebral do Hospital do Servidor Público Estadual de São Paulo, Doutor em Saúde Pública pela Universidade de São Paulo (USP).

2. Knoplich, J:Enfermidades da Coluna Vertebral, $3^{\underline{a}}$ ed, São Paulo, Robe Editorial, 2003.

3. Nacheson A, Jonsson E: Neck and Back Paint. Philadelphia, Lippincott, 2000. 